\title{
Prunella vulgaris L. seeds: a promising source of lipids, proteins, and original phenolic compounds presenting high antioxidant and anti-inflammatory activity
}

\author{
Sabine Danthine ${ }^{(1)}$, Aman Paul ${ }^{(1,2)}$, Olivia Jansen ${ }^{(2)}$, Aurélien Ducrey ${ }^{(2)}$, Aurore Richel ${ }^{(1)}$, \\ Georges Lognay ${ }^{(3)}$, Philippe Maesen ${ }^{(3)}$, Paulin Mutwale Kapepula ${ }^{(2,4,5)}$, Ange Mouithys- \\ Mickalad ${ }^{(4)}$, Thierry Franck ${ }^{(4)}$, Michel Frédérich ${ }^{(2)}$ \\ (1) Université de Liège - Gembloux Agro-Bio Tech. TERRA Research Center. SMARTECH. Gembloux (Belgium). \\ (2) Université de Liège. CIRM. Laboratoire de Pharmacognosie. Liège (Belgium).E-mail: M.Frederich@uliege.be \\ (3) Université de Liège - Gembloux Agro-Bio Tech. Analytical chemistry. Gembloux (Belgium). \\ (4) Université de Liège. CIRM. CORD. Liège (Belgium). \\ ${ }^{(5)}$ Université de Kinshasa. CESNOV. Kinshasa (Democratic Republic of Congo).
}

Received 23 March 2021, accepted 14 December 2021, available online 23 December 2021.

This article is distributed under the terms and conditions of the CC-BY License (http://creativecommons.org/licenses/by/4.0)

Description of the subject. Prunella vulgaris L. (Lamiaceae) is an edible herb used in Europe and Asia as herbal tea, food, dietary supplement or medicinal plant since several centuries. Although the composition and properties of the aerial parts are well documented in the literature, Prunella vulgaris seeds have never been investigated.

Objectives. The aim of this work was to characterize the composition of these seeds to assess not only their nutritional potential (protein, lipid and minerals content), but also their antioxidant and anti-inflammatory potential as well as their specialized metabolites composition.

Method. The protein, lipids and mineral content were determined. The phenolic compounds were isolated; elucidation of their structures was done by means of HR-MS and one- and two-dimensional NMR analysis. They were then evaluated for their biological activity, together with seed extracts.

Results. Omega-3 rich oil and an interesting amino acids profile were detected in the seeds as well as the presence of a high content of polyphenolic compounds, including two structurally new compounds (phenylpropane derivatives) which were isolated and structurally characterized. The two compounds described here for the first time, were named amolsamic acids A\&B. The seeds and amolsamic acids showed an interesting antioxidant potential, and a strong anti-inflammatory activity on neutrophils, MPO and HRP models.

Conclusions. These findings highlight the real health promoting potential of $P$. vulgaris seeds and make them a good candidate as super-food or food supplement.

Keywords. Lamiaceae, secondary metabolites, bioactive compounds, reactive oxygen species, traditional medicines, health foods.

Les graines de Prunella vulgaris L.: une source prometteuse de lipides, protéines et composés phénoliques originaux présentant des activités antioxydante et anti-inflammatoire importantes

Description du sujet. Prunella vulgaris L. (Lamiaceae) est une plante herbacée comestible, utilisée depuis plusieurs siècles en Europe et en Asie comme tisane, aliment, complément alimentaire ou encore plante médicinale. Bien que la composition des parties aériennes ait été étudiée et soit déjà bien documentée, les graines de Prunella vulgaris n'ont jamais été étudiées.

Objectifs. L'objectif de ce travail était d'étudier la composition des graines de P. vulgaris afin d'en déterminer non seulement le potentiel nutritionnel (teneur en lipides, protéines, minéraux), mais aussi la présence de métabolites spéciaux et d'en déterminer les pouvoirs antioxydant et anti-inflammatoire.

Méthode. Les teneurs en protéines, lipides et minéraux des graines ont été déterminées. Les composés phénoliques ont été isolés, la détermination de leur structure a été réalisée par HR-MS et RMN à une et deux dimensions. Leurs activités biologiques ont ensuite été évaluées par différentes méthodes.

Résultats. L'huile contenue dans les graines de $P$. vulgaris est riche en omega-3 ; les graines possèdent un profil en acides aminés intéressant ainsi qu'une teneur élevée en polyphénols. Parmi ceux-ci, deux nouveaux composés ont pu être identifiés 
(dérivés de phénylpropane) et leur structure a été caractérisée. Ces deux composés, décrits pour la première fois dans la nature, ont été nommés acides amolsamic $\mathrm{A} \& \mathrm{~B}$. Ces deux acides amolsamic $\mathrm{A} \& \mathrm{~B}$, de même que les grains dans leur entièreté, ont un potentiel antioxydant et une activité anti-inflammatoire forte (modèles neutrophiles, MPO et HRP).

Conclusions. Ces résultats démontrent que les graines de P. vulgaris ont des effets santés prometteurs, faisant d'elles un candidat intéressant comme super aliment ou complément alimentaire.

Mots-clés. Lamiaceae, métabolites secondaires, composés bioactifs, dérivés réactifs de l'oxygène, médecine douce, aliments fonctionnels.

\section{INTRODUCTION}

Prunella vulgaris L. (Lamiaceae) is a perennial herb from the Lamiaceae family originally distributed in temperate Europe and Asia which is now widespread in all temperate regions of the world, including Africa, America and Australia (Gu et al., 2013; Wang et al., 2019). Commonly named "self-heal" or "heal-all", $P$. vulgaris is used in European traditional medicine since centuries. The whole plant, leaves or fruit spikes, are also commonly consumed as health-promoting food or herbal tea in China (Qu et al., 2017).

In Europe, $P$. vulgaris is used for the treatment of sore throat, intestinal infections, diarrhea, as healing agent and anti-hemorrhagic (Huang et al., 2009; Chevallier, 2016) while in Asia, it is consumed as herbal tea for the treatment of health troubles such as migraine or fevers (Huang et al., 2009; Kalle \& Sõukandal., 2012). In Europe, the plant is also sometimes eaten in its whole and it has been officially approved as dietary supplement in some countries like Belgium (Royal Decree from $29^{\text {th }}$ of August, 1997, about plants in food supplements) and is evaluated at the European level (EFSA, 2011).

Due to its numerous reported traditional medicinal uses and properties, the phytochemical composition and anti-oxidant activity of the aerial parts of $P$. vulgaris have been largely examined; rosmarinic acid, polysaccharides, pentacyclic triterpenes have been identified ( $\mathrm{Gu}$ et al., 2013; Rasool \& Ganai, 2013; Golembiovska, 2014; Wang et al., 2019). Although the composition and properties of the areal parts are well documented in the literature, to the best of our knowledge, P. vulgaris seeds have never been investigated for their proximate, phytochemical composition or potential bioactivities.

Due to global interest for field border flowering strips in Europe (FBFS = portions of agricultural landscape reserved for herbaceous vegetation), the emergence of specialized farming practices dedicated towards the production of seeds from plants commonly grown in those strips has recently emerged (Uyttenbroeck et al., 2016). In Europe, P. vulgaris is one of the species commonly observed in those FBFS. In this context, considering the availability of P.vulgaris seeds in large amount, they potentially represent an interesting biomass for food supplements or the provision of bioactive molecules, that could be of great significance to the pharmaceutical market (Paul et al., 2015).

Thus, the goal of this research was to characterize the lipid, protein and mineral contents, to identify the main phenolic metabolites, as well as the radical scavenging, cellular antioxidant and anti-inflammatory activities of P. vulgaris seeds, in order to assess the nutritional and health potential of these seeds.

\section{MATERIALS AND METHODS}

\subsection{Plant material}

Two different batches of P. vulgaris seeds were purchased from ECOSEM, Belgium (batches 2014/089225 and 2018/089225). A third sample (plant and seeds) was collected in Couthuin, Belgium ( $3^{\text {rd }}$ of July, 2018) by Thomas Braipson and botanically identified by Pr Michel Frédérich. A Voucher specimen was deposited and archived in the herbarium of the Pharmacognosy Department from the University of Liege with the number 2018-07-01.

\subsection{Protein, lipids and mineral content determination}

Protein analysis. The nitrogen content was determined using the Dumas method (AOAC International, 2007); it was then multiplied by 6.25 to obtain the protein content. The amino acid profiles were established according to the method previously described by Paul et al. (2016).

Lipid analysis. The total lipids were quantitatively extracted from the seeds according to Folch procedure, as described in Paul et al. (2016). The fatty acid profile was then determined by GC, as described by Paul et al. (2016). Gravimetric determination of lipid classes (neutral lipids [sterol ester, triacylglycerol, sterols, diacylglycerol and monoacylglycerols], free fatty acids and polar lipids) was performed after SPE fractionation using disposable aminopropyl cartridges (Mega Bond Elut [2 g], Agilent technologies, USA) according to Vaghela \& Kilara (1995). The purity of all recovered fractions was confirmed using thin layer chromatography. 
Mineral analysis. The ash content was determined using the AOAC 942.05 method (2006) (AOAC International, 2007). The mineral composition was investigated by digesting the sample $(500 \mathrm{mg})$ with aqua regia $(5 \mathrm{ml})$. Calcium, $\mathrm{Cu}, \mathrm{Fe}, \mathrm{Mg}, \mathrm{Mn}$ and $\mathrm{Zn}$ concentrations were analyzed using the Perkin Elmer AAS-800 atomic absorption spectrophotometer (Perkin Elmer, USA) while $\mathrm{K}$ and Na contents were analyzed on Perkin Elmer AAS-200 flame emission spectrophotometer (Perkin Elmer, USA) (Loukou et al., 2011).

Cellulose, hemicellulose and lignin analysis. Cellulose, hemicellulose and lignin contents of the defatted biomass were investigated according to Goering \& van Soest (1970).

\subsection{Preparation of seed methanolic extract}

The seeds were ground using an analytical mill A-10 basic mill (IKA-Werke, Germany) to pass through a $1 \mathrm{~mm}$ mesh screen. Seed powders were then stored at $-20{ }^{\circ} \mathrm{C}$, under vacuum to avoid degradation until analysis. To exclude the inference of lipids in further analyses, the seeds were defatted using n-hexane (10 $\mathrm{ml} \mathrm{n}$-hexane $\cdot \mathrm{g}^{-1}$ seeds for $30 \mathrm{~min}$ under continuous stirring) before preparation of methanolic extract $\left(3 \times 10 \mathrm{ml}\right.$ methanol. $\mathrm{g}^{-1}$ defatted seeds for $30 \mathrm{~min}$ under continuous stirring). The methanolic extracts were then filtered and concentrated under reduced pressure to obtain defatted seed methanolic extract (DSME). DSME was kept at $-20{ }^{\circ} \mathrm{C}$ under vacuum until analysis.

\subsection{Analysis of phenolic compounds: total phenolic content and phenolic profile determination}

The total phenolic content of the seeds was investigated using Folin Ciocalteu reagent, as described in European Pharmacopeia (EDQM, 2020). Defatted seed methanolic extract was analyzed using an Agilent 1,000 series chromatogram with UV-Diode array detector (Agilent Technologies, USA) fitted with a Hypersil ODS RP-18 column (Thermo Fisher Scientific, Belgium). Defatted seed methanolic extract solution $\left(10 \mathrm{mg} \cdot \mathrm{ml}^{-1}\right.$ methanol) was filtered $(0.45 \mu$ membrane) and separated at $20^{\circ} \mathrm{C}$ at a flow rate of $1 \mathrm{ml} \cdot \mathrm{min}^{-1}$. The mobile phase consisted of solvent A (acetonitrile) and solvent B (0.05\% trifluoroacetic acid) in gradient mode. Following gradient was used for the analysis: $0 \mathrm{~min}(0 \% \mathrm{~A}, 100 \% \mathrm{~B}), 1 \mathrm{~min}(3 \%$ A, $97 \%$ B), $45 \min (40 \%$ A, $60 \%$ B), $55 \min (40 \%$ A, $60 \%$ B), $56 \min (60 \%$ A, $40 \%$ B), $66 \min (60 \%$ A, $40 \%$ B), $67 \mathrm{~min}(0 \% \mathrm{~A}, 100 \% \mathrm{~B})$ and $82 \mathrm{~min}(0 \% \mathrm{~A}, 100 \%$ B). The phenolic compounds were identified based on the comparison of retention times and UV spectra with internal spectral database and co-injection of references. Quantitative analysis of the identified compounds was performed with external calibration. The unidentified compounds were separated by preparative HPLC using Varian Prostar HPLC system with a UV-Diode Array Detector (Agilent Technologies, USA), and a $12 \mu \mathrm{m}$ Lichrospher 100 RP-18 column (Merck Millipore, Belgium). Defatted seed methanolic extract $(500 \mathrm{mg})$ was dissolved in $10 \mathrm{ml}$ water/methanol solution $(4: 1$ $\mathrm{v} / \mathrm{v}$ ) using ultrasound at $25^{\circ} \mathrm{C}$ for $10 \mathrm{~min}$. The raw extract was filtered (using $0.45 \mu$ membrane) and injected into the preparative HPLC system. Mobile phase and gradient conditions were established according to upscaling equations. The separated fractions were evaporated under reduced pressure and identified using NMR and MS spectroscopy. The UV spectra were obtained on a methanol solution using a Kontron Uvikon Spectrophotometer. The IR spectra were recorded using a Spectrum 1,000 (Perkin Elmer, Waltham, MA, USA) FT-IR spectrometer with a DTGS 134 detector. NMR spectra were recorded in methanol-d4 with a Bruker Advance NEO $500 \mathrm{MHz}$ spectrometer equipped with a cryoprobe and using standard Bruker experiments and TMS as the internal reference. Mass spectrometry (MS) was carried out using a micromass ESI-Q-TOF II instrument (Waters) using ESI-ionization in negative mode in the $\mathrm{m} / \mathrm{z}$ range 100-1,500.

\subsection{Radical scavenging, cellular antioxidant and anti-inflammatory activities}

Radical scavenging activity. The in vitro radical scavenging activity of the DSME was investigated using 2, 2-diphenyl-1-picryhydrazyl (DPPH) and 2,2-azinobis (3-ethylbenzothiazoline)-6 sulphonic acid (ABTS) assays. The DPPH and ABTS assays were performed according to the method described respectively by Floegel et al. (2011) and Franck et al. (2013). These assays were performed at final concentrations: 1, 5, 15,30 and $60 \mu \mathrm{g} \cdot \mathrm{ml}^{-1}$ DSME. Gallic acid was used as the reference molecule, at final concentration of 1 , 2.5 and $5 \mu \mathrm{g} \cdot \mathrm{ml}^{-1}$ for DPPH; and $0.1,0.5$ and $1 \mu \mathrm{g} \cdot \mathrm{ml}^{-1}$ for ABTS. Relative free radical scavenging activity of the sample, in comparison to DMSO control, was expressed as $\mathrm{IC}_{50}$ value.

Cellular antioxidant activity on the oxidative response of activated neutrophils. The reactive oxygen species (ROS) produced by activated neutrophils were measured by lucigenin-enhanced chemiluminescence (CL) based on the method previously described by Benbarek et al. (1999) and slightly modified by Franck et al. (2005). The effect of DSME on the ROS production by activated neutrophils was investigated as previously described (Franck et al., 2013). DSME was 
prepared in DMSO and diluted at final concentrations of $0.1,0.5,1,5$ and $10 \mu \mathrm{g} \cdot \mathrm{ml}^{-1}$. The control was performed with PMNs activated with PMA in the presence of PBS instead of the plant extract and was taken as $100 \%$ CL response compared to gallic acid, used as the reference molecule, at final concentration of $0.175,1.75$ and $17.5 \mu \mathrm{g} \cdot \mathrm{ml}^{-1}$ ). Relative inhibition of ROS production by tested sample versus DMSO control was expressed as $\mathrm{IC}_{50}$ value.

In order to verify whether the antioxidant activity observed for DSME towards ROS produced by PMAactivated neutrophils was not due to their toxicity, cell viability (on $10^{6}$ neutrophils; final concentration of DSME 5 and $10 \mu \mathrm{g} \cdot \mathrm{ml}^{-1}$ ) was analyzed using classical Trypan blue exclusion assay.

Anti-inflammatory activity on the oxidative response of myeloperoxidase enzyme. The equine myeloperoxidase (MPO) was isolated and purified using the method described by Franck et al. (2005). The anti-inflammatory effect of DSME on the MPO activity was measured using two techniques: Direct response \& Indirect response using Specific ImmunoExtraction Followed by Enzyme Detection (SIEFED) (Franck et al., 2005). In both assays production of resorufin from Amplex red was analyzed at $37^{\circ} \mathrm{C}$ for 30 min using a Fluoroskan Ascent 96 plate reader. These assays were performed at final concentrations of $1,5,10$ and $25 \mu \mathrm{g} \cdot \mathrm{ml}^{-1}$ DSME. Gallic acid was used as reference compound (at final concentrations of $0.175,1.75$ and $\left.17.5 \mu \mathrm{g} \cdot \mathrm{ml}^{-1}\right)$. Relative activity of sample in comparison to DMSO control was expressed as $\mathrm{IC}_{50}$ value.

Horseradish peroxidase (HRP) catalyzed oxidation. The modulatory activity of DSME on the horseradish peroxidase (HRP) $/ \mathrm{H}_{2} \mathrm{O}_{2}$ oxidation response was measured using L012 probe (luminol analogue) (Wako Chemicals, Neuss, Germany). Briefly, $2 \mu 1$ of DSME in DMSO solution was suspended with $153 \mu 1$ PBS (pH 7.4), $5 \mu 1$ HRP solution $\left(25 \mu \mathrm{g} \cdot \mathrm{ml}^{-1}\right), 20 \mu 1 \mathrm{~L} 012$ solution $(1 \mu \mathrm{M})$ and $20 \mu 1 \mathrm{H} 202(1 \mathrm{mM})$. This was immediately followed by measurement of fluorescence using Fluoroskan Ascent 96 plate reader for $30 \mathrm{~min}$ at $37^{\circ} \mathrm{C}$. The assay was performed at final concentrations: 1,10 , 20, 40 and $80 \mu \mathrm{g} \cdot \mathrm{ml}^{-1}$ DSME. Gallic acid was used as the reference molecule (at final concentrations of $0.1,1$ and $\left.10 \mu \mathrm{g} \cdot \mathrm{ml}^{-1}\right)$. Relative activity of sample in comparison to DMSO control was expressed as $\mathrm{IC}_{50}$ value.

\subsection{Statistical analysis}

Results are expressed as mean \pm standard deviation. All the investigations realized in this study were performed in triplicate (besides total phenolic content and amino acid profile, which were performed in duplicate). The $\mathrm{IC}_{50}$ values of $\mathrm{DPPH}$ radical scavenging activity were calculated using GraphPad Prism 6 software. Statistical difference between $\mathrm{IC}_{50}$ values were analyzed by one-way ANOVA with Fischer Least Significance Difference method on Minitab 17 software (at 95\% confidence level).

\section{RESULTS}

\subsection{Proximate composition of $\boldsymbol{P}$. vulgaris seeds}

The protein content of P.vulgaris seeds was $16.92 \pm 1.23 \%$ on dry basis. The total lipid content of P. vulgaris seeds is $16.12 \pm 0.17 \%$ on dry basis. The main lipid constituents (classes) and fatty acid composition and the amino acids profile are reported in table 1.

The chemical score according to FAO/WHO (WHO, 2007) reference pattern is shown in table 2. Ash content of P. vulgaris seeds is $4.89 \pm 0.05 \%$ on dry weight and concentration of the main individual minerals are reported in table $\mathbf{3}$, as well as the lignocellulosic components content.

\subsection{Phenolic composition}

The seeds yielded $2.31 \pm 0.04 \%$ DSME on dry basis. The total phenolic content of P. vulgaris seeds is $8.38 \pm 0.50 \mathrm{mg} \cdot \mathrm{g}^{-1}$ pyrogallol equivalents (dry basis). The phenolic profile obtained by HPLC is presented in figure 1.

Two compounds: caffeic acid (20.99 min) and rosmarinic acid (33.1 min) were unambiguously identified and their proportions were of $1.85 \pm 0.05$ and $0.03 \pm 0.00 \%$ respectively. The three other major compounds were separated using preparative HPLC to give salviaflaside (rosmarinic acid O-glycoside) $(\mathrm{RT}=29.2 \mathrm{~min}$ ). Two new compounds (corresponding to peaks at 40.2 and $41.6 \mathrm{~min}$ ) were then isolated. They were named amolsamic acid A (1) and B (2), respectively. The structures of these compounds (Figure 2) were established according to their UV, IR, ESI-MS and NMR spectral data. ${ }^{1} \mathrm{H}$ and ${ }^{13} \mathrm{C}$ NMR data are presented in table $\mathbf{4}$ and in figure 3a-d.

Compound 1 was obtained as a white amorphous powder. ESI-MS spectra in the negative ion mode showed a [M-H]-peak at $m / z 715.1306$ (corresponding to $\mathrm{C}_{36} \mathrm{H}_{28} \mathrm{O}_{16}$ ) and indicating 23 degrees of insaturation. ${ }^{13} \mathrm{C}-\mathrm{NMR}$ data showed the occurrence of 36 carbons, $2 \mathrm{CH}_{2}, 15 \mathrm{CH}$ and $19 \mathrm{C}$. Compound 2 was also obtained as a white amorphous powder. ESI-MS spectra in the negative ion mode showed a $[\mathrm{M}-\mathrm{H}]-$ peak at $\mathrm{m} / \mathrm{z} 1071.1840$ (corresponding to $\mathrm{C}_{54} \mathrm{H}_{40} \mathrm{O}_{24}$ ) 
Table 1. Lipid classes, fatty acid and amino acid profile of Prunella vulgaris seeds - Classes de lipides, profil des acides gras et des acides aminés des graines de Prunella vulgaris.

\begin{tabular}{|c|c|c|c|c|c|}
\hline Fatty acid & $\%$ of total fatty acids ${ }^{\mathrm{a}}$ & Lipid classes & $\%$ & Amino acid & $\%$ of total amino acids ${ }^{b}$ \\
\hline C 16:0 & $8.46 \pm 0.30$ & Neutral lipids & $98.39 \pm 0.12$ & Aspartic acid & $9.00 \pm 0.01$ \\
\hline C 18:0 & $1.85 \pm 0.02$ & TAG & $96.81 \pm 0.20$ & Threonine $^{e}$ & $3.11 \pm 0.03$ \\
\hline C $18: 1$ & $13.23 \pm 0.12$ & Sterols & $2.03 \pm 0.14$ & Serine & $5.62 \pm 0.06$ \\
\hline C 18:2 n6 & $17.44 \pm 0.17$ & DAG & $0.66 \pm 0.06$ & Glutamic acid & $21.93 \pm 0.16$ \\
\hline C $18: 3 \mathbf{n} 3$ & $55.29 \pm 0.08$ & MAG & $0.50 \pm 0.07$ & Proline & $3.54 \pm 0.07$ \\
\hline C 20:0 & 0 & & & Glycine & $5.56 \pm 0.07$ \\
\hline C 20:1 n9 & $0.47 \pm 0.02$ & FFA & $1.00 \pm 0.05$ & Alanine & $4.76 \pm 0.08$ \\
\hline C 22:0 & 0 & Polar lipids & $0.61 \pm 0.06$ & Valine $^{e}$ & $3.89 \pm 0.02$ \\
\hline C $22.6+$ C 24.1 & $0.13 \pm 0.12$ & & & Methionine $^{e}$ & $1.28 \pm 0.03$ \\
\hline Others & $3.13 \pm 0.53$ & & & Cyanuric acid & $3.47 \pm 0.37$ \\
\hline \multirow[t]{12}{*}{ Iodine value } & $186.58 \pm 0.62$ & & & Isoleucine $e^{\mathrm{e}}$ & $3.02 \pm 0.021$ \\
\hline & & & & Leucine $^{\mathrm{e}}$ & $6.45 \pm 0.03$ \\
\hline & & & & Tyrosine & $2.90 \pm 0.01$ \\
\hline & & & & Phenylalanine $^{\mathrm{e}}$ & $4.87 \pm 0.04$ \\
\hline & & & & Histidine $^{e}$ & $2.68 \pm 0.03$ \\
\hline & & & & Lysine $^{\mathrm{e}}$ & $3.31 \pm 0.00$ \\
\hline & & & & Arginine & $11.29 \pm 0.02$ \\
\hline & & & & Cysteine $^{e}$ & $0.74 \pm 0.15$ \\
\hline & & & & Methionine sulfone & $2.55 \pm 0.12$ \\
\hline & & & & $\%$ EAA & 29.37 \\
\hline & & & & $\%$ NEA & 70.63 \\
\hline & & & & $\%$ EAA $/ \%$ NEA & 0.42 \\
\hline
\end{tabular}

Results are expressed as mean \pm standard deviation - les résultats sont exprimés en moyenne \pm écart-type; ${ }^{\mathrm{a}}: \mathrm{n}=3 ;{ }^{\mathrm{b}}: \mathrm{n}=2 ;{ }^{\mathrm{e}}:$ essential amino acid - acide aminé essentiel; EAA: essential amino acids - acides aminés essentiels; NEA: non-essential amino acids - acides aminés non essentiels.

Table 2. Prunella vulgaris seeds amino acids content and FAO/WHO chemical score - Contenu en acides aminés des graines de Prunella vulgaris et score chimique FAO/WHO.

\begin{tabular}{|c|c|c|c|}
\hline \multirow[t]{2}{*}{ Amino acid } & \multirow{2}{*}{$\begin{array}{l}\text { Content }\left(\mathrm{mg} \cdot \mathrm{g}^{-1} \text { protein }\right) \\
\text { FAO/WHO }(\mathbf{1 9 9 0}) \text { reference pattern }\end{array}$} & \multirow{2}{*}{$\frac{\text { Content }\left(\mathrm{mg} \cdot \mathrm{g}^{-1} \text { protein) }\right.}{\text { Prunella vulgaris seeds (present paper) }}$} & \multirow[t]{2}{*}{ Score } \\
\hline & & & \\
\hline Isoleucine & 28 & 30.2 & 107.86 \\
\hline Leucine & 77 & 64.5 & 83.77 \\
\hline Lysine & 58 & 33.1 & $57.07^{\mathrm{a}}$ \\
\hline Methionine + cystine & 25 & 20.2 & 80.80 \\
\hline Phenylalanin + tyrosine & 63 & 77.7 & 123.33 \\
\hline Threonine & 34 & 31.1 & 91.47 \\
\hline Valine & 35 & 38.9 & 111.14 \\
\hline
\end{tabular}

a: first limiting amino acid according to the FAO/WHO (WHO, 2007) reference pattern - premier acide aminé limitant selon le schéma de référence FAO/OMS (OMS, 2007). 
Table 3. Mineral profile and lignocellulosic components of Prunella vulgaris seeds - Profil minéral et composants lignocellulosiques des graines de Prunella vulgaris.

\begin{tabular}{lclc}
\hline Mineral (per kg dry matter) & Prunella vulgaris & Lignocellulosic constituents & \% of defatted seeds, dry basis \\
\hline $\mathrm{Ca}(\mathrm{g})$ & $6.63 \pm 0.05$ & Cellulose & $24 \pm 1.21$ \\
$\mathrm{~K}(\mathrm{~g})$ & $7.60 \pm 0.03$ & Hemicellulose & $25 \pm 1.28$ \\
$\mathrm{Mg}(\mathrm{g})$ & $3.81 \pm 0.11$ & Lignin & $12 \pm 1.72$ \\
$\mathrm{Na}(\mathrm{g})$ & $0.34 \pm 0.01$ & & \\
$\mathrm{Cu}(\mathrm{mg})$ & $16.76 \pm 0.18$ & & \\
$\mathrm{Zn}(\mathrm{mg})$ & $39.92 \pm 0.78$ & & \\
$\mathrm{Fe}(\mathrm{mg})$ & $156.10 \pm 1.80$ & & \\
$\mathrm{Mn}(\mathrm{mg})$ & $55.40 \pm 0.97$ & & \\
\hline
\end{tabular}

Results are expressed as mean \pm standard deviation - les résultats sont exprimés en moyenne \pm écart-type $; \mathrm{n}=3$.

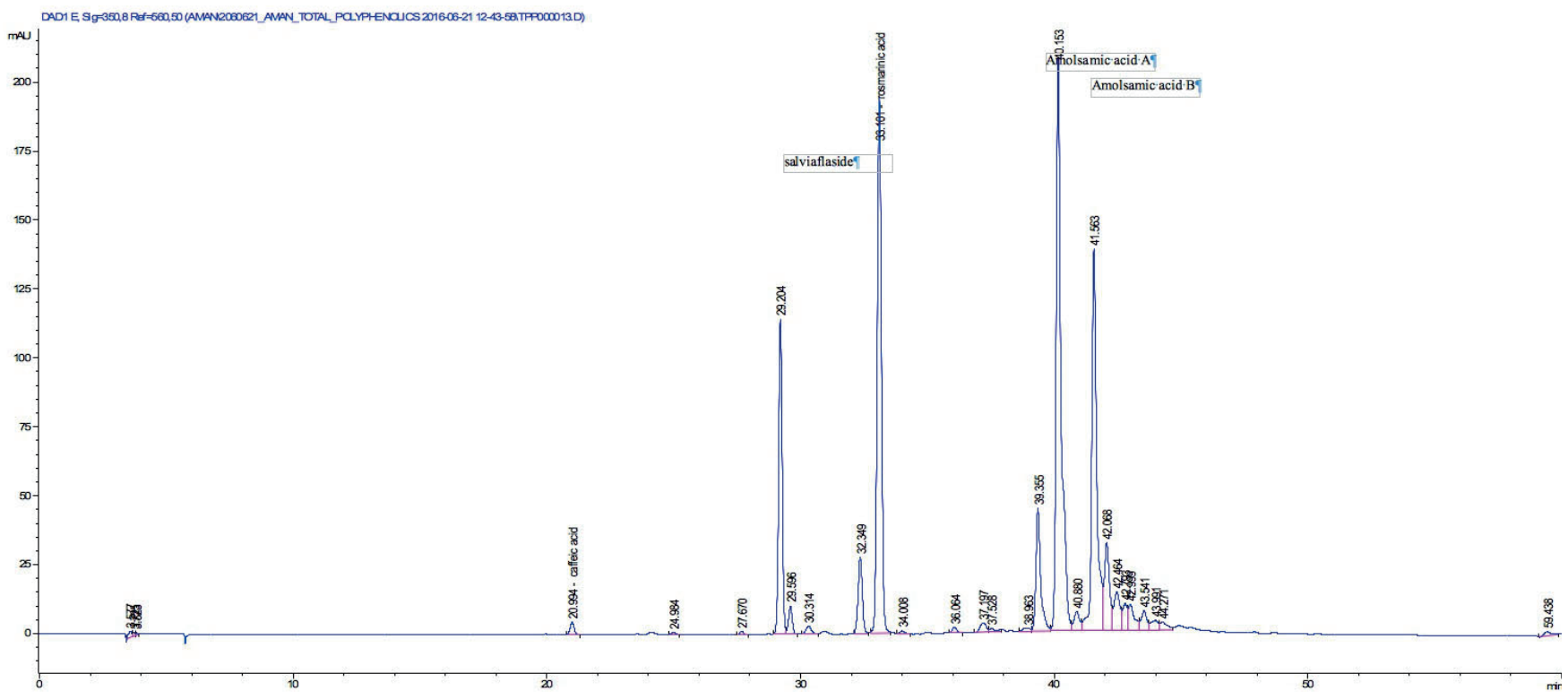

Figure 1. HPLC profile of Prunella vulgaris defatted seeds methanolic extract - Profil HPLC de l'extrait méthanolique des graines dégraissées de Prunella vulgaris.

and indicating 35 degrees of insaturation. ${ }^{13} \mathrm{C}$-NMR data showed the presence of 54 carbons, $3 \mathrm{CH}_{2}, 21$ $\mathrm{CH}$ and $30 \mathrm{C}$.

\subsection{Free radical scavenging activity}

The results obtained for DPPH and ABTS antioxidant activities for the P. vulgaris DSME and gallic acid are presented in table 5 (radical scavenging activities).

\subsection{Cellular anti-oxidant activity on the oxidative response of activated neutrophils}

Cellular antioxidant activities as a function of concentration for the P. vulgaris DSME and gallic acid are presented in figure 4a-c.

\subsection{Anti-inflammatory activity on the oxidative response of myeloperoxidase enzyme}

The activity obtained using the direct and SIEFED assays is shown in figure $\mathbf{4 b}$. Similar concentrations were used in both the assays to estimate the comparative activity. In both direct and SIEFED assays, a dose dependent increase in MPO inhibition activity was observed.

\subsection{Horseradish peroxidase (HRP)-catalyzed oxidation}

As for neutrophil and MPO models, a dose-dependent inhibitory activity of L012 oxidation catalyzed by $\mathrm{HRP} / \mathrm{H}_{2} \mathrm{O}_{2}$ was observed in the presence of increasing 


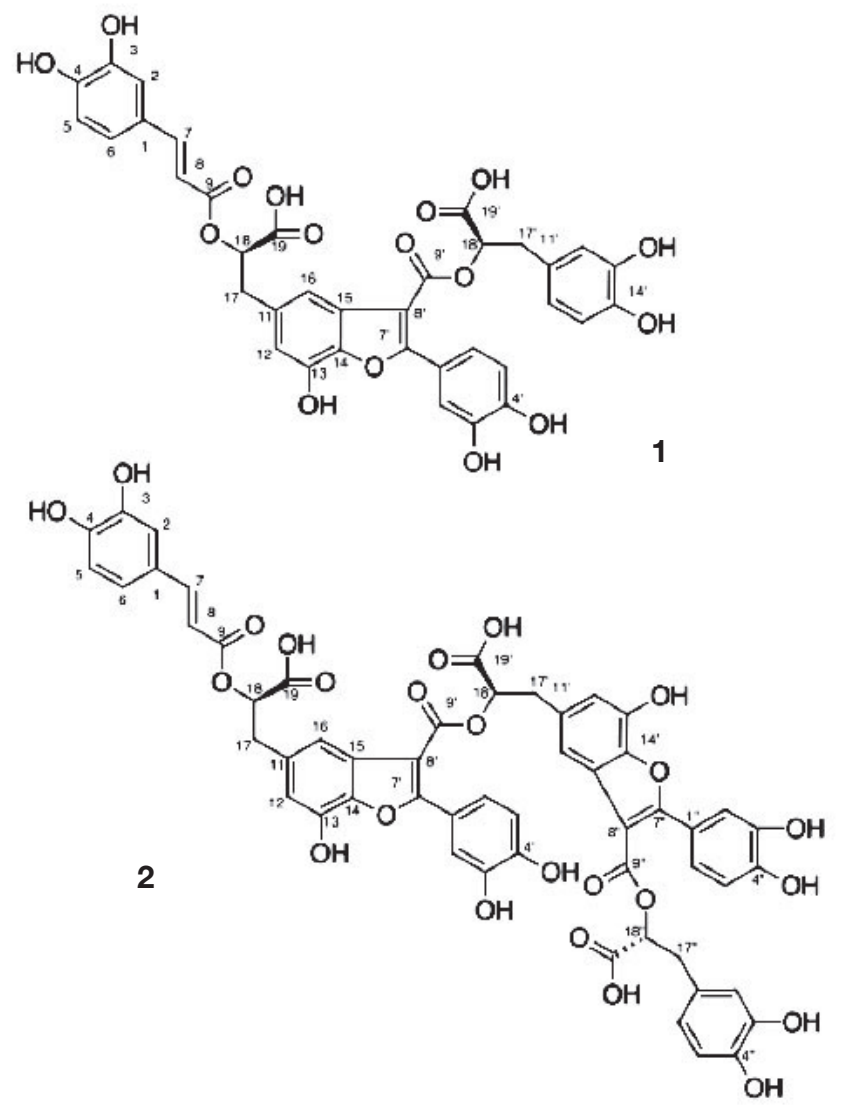

Figure 2. Structures of amolsamic acid A and amolsamic acid B - Structures de l'acide amolsamique A et de l'acide amolsamique $B$.

concentrations of DSME (Figure 4c). An $\mathrm{IC}_{50}$ of 10.7 and $0.9 \mu \mathrm{g} \cdot \mathrm{ml}^{-1}$ was obtained for $P$. vulgaris DSME and gallic acid respectively.

\section{DISCUSSION}

The aim of this work was to characterize the composition of $P$. vulgaris seeds to assess not only their nutritional potential (protein, lipid and minerals content), but also their antioxidant and anti-inflammatory properties as well as their specialized metabolites composition.

Regarding the gross composition, P. vulgaris has an interesting protein content, which resembles the protein content of flaxseed (18\%, non-dried basis) or chia seeds (16-26\%, non-dried basis) (Melo et al., 2019), seeds which are used as super food for human consumption in Europe. The total protein content of a material is important; however, from a nutritional point of view the nutritional quality of proteins is mainly dependent on their amino acid composition. Prunella vulgaris amino acids profile is obviously interesting from a nutritional point of view as P. vulgaris seeds contain high amount of essential amino acids (EAA).
According to the recommendations made by the Belgian CSS (Conseil Supérieur de la Santé - Health High Council) in 2016, $100 \mathrm{~g}$ of P. vulgaris seeds are enough to cover around $50 \%$ of the daily recommended intake of EAA for an adult of $70 \mathrm{~kg}$ (SPF Santé Publique, 2016). The lipid content of P. vulgaris seeds resembles the lipid content of some commercially used lipid sources such as soy bean (18-20\%) or rice bran (18-24\%) (Gunstone et al., 1994). Prunella vulgaris seed oil contain comparable level (72-73\%) of PUFA to chia seeds $(80 \%)$ or Cannabis sativa seeds $(71 \%)$ (Montserrat-de-la-Paz et al., 2014). Interestingly, two important essential FA, $\alpha$-linolenic acid (ALA) $(>55 \%)$ and linoleic acid (LNA) $(>17 \%)$, as well as oleic acid (OA) $(>13 \%)$ are the major constituents of P. vulgaris lipids. The FA profile of P. vulgaris oil is better than the one of rapeseed oil which is now recommended in food nutrition to optimize the omega $6 / 3$ ratio. According to the recommendations made by the Belgian CSS in 2016, MUFA+PUFA should represent at least two third of the total daily ingested lipids. Consuming P. vulgaris seeds in the diet could help to reach this target. Prunella vulgaris seed oil contains $\alpha$-linolenic acid levels similar to the oil from chia seeds and flaxseeds, which are two commercially used omega-3 fatty acid food supplements. Linolenic acid content of chia seeds and flaxseeds is $52-63 \%$ and 35-60\%, respectively (Gunstone, 2011).

Regarding the total phenolic content, a comparison with data reported by Sárosi et al. (2011) indicates that P. vulgaris seeds offer a highly better source of phenolics when compared to the aerial parts that possess a total phenolic content ranging between 0.28 and $0.70 \mathrm{mg} \cdot \mathrm{g}^{-1}$ gallic acid equivalents (dry basis).

The identification of the phenolic compounds revealed the presence of caffeic acid, rosmarinic acid and salviaflaside (rosmarinic acid O-glycoside) $(\mathrm{RT}=29.2 \mathrm{~min})$, this compound was also reported as present in aerial parts, it was identified thanks to the comparison of MS and NMR data with literature (Tezuka et al., 1998). Besides those known compounds, the presence of two unknown compounds was also detected. The molecular formula of the new Compound 1, named amolsamic acid A, corresponded to two rosmarinic acid moieties. The NMR data of compound 1 were very similar to those of schizotenuin A (Matsuta et al., 1996), but presented differences in the NMR spectra at the junction point between the two rosmarinic moieties. Schizotenuin A presented a junction between the two caffeic acid moieties, when compound 1 presented a junction between one caffeoyl moiety and one dihydrocaffeoyl moiety. The junctions C-9 - O - C-18 and C-8' - C-15 were confirmed by HMBC correlations between $\mathrm{H}-18$ and $\mathrm{C}-9$; $\mathrm{H}-16$ and C-8', C17. Compared to compound 1, MS data for compound 2 (amolsamic acid B) indicated three 
Table 4. ${ }^{1} \mathrm{H}$ and ${ }^{13} \mathrm{C}$ NMR data of compounds 1 and 2 in deuterated DMSO - Données de RMN ${ }^{1} H$ et ${ }^{13} \mathrm{C}$ des composés 1 et 2 dans le DMSO deutéré.

\begin{tabular}{|c|c|c|c|c|c|c|c|c|}
\hline \multirow[t]{2}{*}{ No } & \multicolumn{4}{|c|}{ Amolsamic acid A (1) } & \multicolumn{4}{|c|}{ Amolsamic acid B (2) } \\
\hline & $\begin{array}{l}\text { Atom } \\
\text { type }\end{array}$ & $\begin{array}{l}\boldsymbol{\delta}_{\mathrm{H}} \\
\text { (Multiplicity, J, nH) }\end{array}$ & $\delta_{\mathrm{C}}$ & $\begin{array}{l}\text { HMBC } \\
(\mathrm{H}-\mathrm{C})\end{array}$ & $\begin{array}{l}\text { Atom } \\
\text { type }\end{array}$ & $\begin{array}{l}\boldsymbol{\delta}_{\mathrm{H}} \\
\text { (Multiplicity, J, nH) }\end{array}$ & $\boldsymbol{\delta}_{\mathrm{C}}$ & $\begin{array}{l}\text { HMBC } \\
(\mathrm{H}-\mathrm{C})\end{array}$ \\
\hline 1 & $\mathrm{C}$ & - & 127.6 & - & $\mathrm{C}$ & - & 127.6 & - \\
\hline $1^{\prime}$ & $\mathrm{C}$ & - & 122.3 & - & $\mathrm{C}$ & - & 122.4 & - \\
\hline $1 "$ & - & - & - & - & $\mathrm{C}$ & - & 122.2 & - \\
\hline 2 & $\mathrm{CH}$ & $7.04(\mathrm{~d}, 2.0 \mathrm{~Hz}, 1 \mathrm{H})$ & 115.2 & 4,6 & $\mathrm{CH}$ & $6.99(\mathrm{~d}, 2.0 \mathrm{~Hz})$ & 115.1 & 6,7 \\
\hline $2^{\prime}$ & $\mathrm{CH}$ & $7.51(\mathrm{~d}, 2.2 \mathrm{~Hz}, 1 \mathrm{H})$ & 117.6 & $4^{\prime}, 6^{\prime}, 7^{\prime}$ & $\mathrm{CH}$ & $7.50(\mathrm{~d}, 2.1 \mathrm{~Hz})$ & 117.4 & $4^{\prime}, 6^{\prime}, 7^{\prime}$ \\
\hline $2 "$ & - & - & - & - & $\mathrm{CH}$ & $7.52(\mathrm{~d}, 2.1 \mathrm{~Hz})$ & 117.7 & $4 ", 6 ", 7 ”$ \\
\hline 3 & $\mathrm{C}$ & - & 146.7 & - & $\mathrm{C}$ & - & 146.6 & - \\
\hline 3 ' & $\mathrm{C}$ & - & 145.9 & - & $\mathrm{C}$ & - & 145.8 & - \\
\hline $3 "$ & - & - & - & - & $\mathrm{C}$ & - & 145.8 & - \\
\hline 4 & $\mathrm{C}$ & - & 149.7 & - & $\mathrm{C}$ & - & 149.6 & - \\
\hline $4^{\prime}$ & $\mathrm{C}$ & - & 149.1 & - & $\mathrm{C}$ & - & 149.0 & - \\
\hline $4 "$ & - & - & - & - & $\mathrm{C}$ & - & 149.0 & - \\
\hline 5 & $\mathrm{CH}$ & $6.78(\mathrm{~d}, \mathrm{~Hz}, 1 \mathrm{H})$ & 116.5 & 1,3 & $\mathrm{CH}$ & $6.73(\mathrm{~m})$ & 116.5 & 1 \\
\hline 5 & $\mathrm{CH}$ & $6.85(\mathrm{~d}, 8.4 \mathrm{~Hz}, 1 \mathrm{H})$ & 115.9 & $1^{\prime}, 3^{\prime}$ & $\mathrm{CH}$ & $6.85(\mathrm{~m})$ & 115.9 & $1^{\prime}, 3^{\prime}$ \\
\hline $5 "$ & - & - & - & - & $\mathrm{CH}$ & $6.85(\mathrm{~m})$ & 115.9 & $1 ", 3 "$ \\
\hline 6 & $\mathrm{CH}$ & $6.92(\mathrm{dd}, 8.2,2.1 \mathrm{~Hz}, 1 \mathrm{H})$ & 123.4 & 2,4 & $\mathrm{CH}$ & $6.85(\mathrm{~m})$ & 123.6 & - \\
\hline $6{ }^{\prime}$ & $\mathrm{CH}$ & $7.42(\mathrm{dd}, 8.4,2.2 \mathrm{~Hz}, 1 \mathrm{H})$ & 123.4 & $7^{\prime}$ & $\mathrm{CH}$ & $7.42(\mathrm{~m})$ & 123.3 & 7 \\
\hline $6 "$ & - & - & - & - & $\mathrm{CH}$ & $7.40(\mathrm{~m})$ & 123.3 & $2 ", 4 ", 7 "$ \\
\hline 7 & $\mathrm{CH}$ & $7.53(\mathrm{~d}, 15.8 \mathrm{~Hz}, 1 \mathrm{H})$ & 147.8 & 9 & $\mathrm{CH}$ & $7.45(\mathrm{~d}, 15.9 \mathrm{~Hz})$ & 147.7 & 1,9 \\
\hline 7 & $\mathrm{C}$ & - & 163.3 & - & $\mathrm{C}$ & - & 163.4 & - \\
\hline $7 "$ & - & - & - & - & $\mathrm{C}$ & - & 163.1 & - \\
\hline 8 & $\mathrm{CH}$ & $6.26(\mathrm{~d}, 15.9 \mathrm{~Hz}, 1 \mathrm{H})$ & 114.4 & 1,9 & $\mathrm{CH}$ & $6.18(\mathrm{~d}, 15.9 \mathrm{~Hz})$ & 114.4 & 1 \\
\hline $8^{\prime}$ & $\mathrm{C}$ & - & 107.8 & - & $\mathrm{C}$ & - & 107.9 & - \\
\hline $8 "$ & - & - & - & - & $\mathrm{C}$ & - & 107.9 & - \\
\hline 9 & $\mathrm{C}$ & - & 168.6 & - & $\mathrm{C}$ & - & 168.6 & - \\
\hline $9^{\prime}$ & $\mathrm{C}$ & - & 165.4 & - & $\mathrm{C}$ & - & 165.5 & - \\
\hline $9 "$ & - & - & - & - & $\mathrm{C}$ & - & 165.3 & - \\
\hline 11 & $\mathrm{C}$ & - & 134.5 & - & $\mathrm{C}$ & - & 134.5 & - \\
\hline $11^{\prime}$ & $\mathrm{C}$ & - & 129.3 & - & $\mathrm{C}$ & - & 134.5 & - \\
\hline $11 "$ & - & - & - & - & $\mathrm{C}$ & - & 129.2 & - \\
\hline 12 & $\mathrm{CH}$ & $6.76(\mathrm{~s}, 1 \mathrm{H})$ & 113.5 & 14,16 & $\mathrm{CH}$ & $6.73(\mathrm{~m})$ & 113.7 & $14,16,17$ \\
\hline $12^{\prime}$ & $\mathrm{CH}$ & $6.71(\mathrm{~d}, 2.1 \mathrm{~Hz}, 1 \mathrm{H})$ & 117.2 & $16^{\prime}$ & $\mathrm{CH}$ & $6.73(\mathrm{~m})$ & 113.6 & $14^{\prime}, 16^{\prime}, 17^{\prime}$ \\
\hline $12 "$ & - & - & - & - & $\mathrm{CH}$ & $6.66(\mathrm{~d}, 1.9 \mathrm{~Hz})$ & 117.2 & $16 ", 17 "$ \\
\hline 13 & $\mathrm{C}$ & - & 142.9 & - & $\mathrm{C}$ & - & 142.9 & - \\
\hline $13^{\prime}$ & $\mathrm{C}$ & - & 146.2 & - & $\mathrm{C}$ & - & 142.9 & - \\
\hline $13 "$ & - & - & - & - & $\mathrm{C}$ & - & 146.1 & - \\
\hline 14 & $\mathrm{C}$ & - & 142.8 & - & $\mathrm{C}$ & - & 142.8 & - \\
\hline $14^{\prime}$ & $\mathrm{C}$ & - & 145.2 & - & $\mathrm{C}$ & - & 142.8 & - \\
\hline
\end{tabular}


Table 4 (continued). ${ }^{1} \mathrm{H}$ and ${ }^{13} \mathrm{C}$ NMR data of compounds 1 and 2 in deuterated DMSO - Données de RMN ${ }^{1} \mathrm{H}$ et ${ }^{13} \mathrm{C}$ des composés 1 et 2 dans le DMSO deutéré.

\begin{tabular}{|c|c|c|c|c|c|c|c|c|}
\hline \multirow[t]{2}{*}{ No } & \multicolumn{4}{|c|}{ Amolsamic acid A (1) } & \multicolumn{4}{|c|}{ Amolsamic acid B (2) } \\
\hline & $\begin{array}{l}\text { Atom } \\
\text { type }\end{array}$ & $\begin{array}{l}\delta_{\mathrm{H}} \\
\text { (Multiplicity, J, nH) }\end{array}$ & $\delta_{\mathrm{c}}$ & HMBC (H-C) & $\begin{array}{l}\text { Atom } \\
\text { type }\end{array}$ & $\begin{array}{l}\delta_{\mathrm{H}} \\
\text { (Multiplicity, J, nH) }\end{array}$ & $\delta_{\mathrm{c}}$ & $\begin{array}{l}\text { HMBC } \\
\text { (H-C) }\end{array}$ \\
\hline $14 "$ & - & - & - & - & $\mathrm{C}$ & - & 145.1 & - \\
\hline 15 & $\mathrm{C}$ & - & 130.1 & - & $\mathrm{C}$ & - & 130.1 & - \\
\hline 15, & $\mathrm{CH}$ & $6.67(\mathrm{~d}, 8.0 \mathrm{~Hz}, 1 \mathrm{H})$ & 116.5 & $11^{\prime}, 13^{\prime}$ & $\mathrm{C}$ & - & 130.3 & - \\
\hline $15 "$ & - & - & - & - & $\mathrm{CH}$ & $6.62(\mathrm{~d}, 8.2 \mathrm{~Hz})$ & 116.4 & $11 ", 13 "$ \\
\hline 16 & $\mathrm{CH}$ & $7.31(\mathrm{~d}, 1.2 \mathrm{~Hz}, 1 \mathrm{H})$ & 115.3 & $8^{\prime}, 12,14$ & $\mathrm{CH}$ & $7.30(\mathrm{~s})$ & 115.3 & $\begin{array}{l}8^{\prime}, 12,14 \\
, 18\end{array}$ \\
\hline $16^{\prime}$ & $\mathrm{CH}$ & $6.51(\mathrm{dd}, 8.1,2.1 \mathrm{~Hz}, 1 \mathrm{H})$ & 122.0 & $12^{\prime}, 14^{\prime}$ & $\mathrm{CH}$ & $7.26(\mathrm{~s})$ & 115.5 & $\begin{array}{l}8^{\prime \prime}, \quad 12^{\prime} \\
14^{\prime}, 17^{\prime}\end{array}$ \\
\hline $16 "$ & $\mathrm{CH}$ & $6.40(\mathrm{dd}, 8.1,2.0 \mathrm{~Hz})$ & 122.1 & $14 ", 17^{\prime \prime}$ & & & & \\
\hline 17 & $\mathrm{CH} 2$ & $3.26,3.18(\mathrm{~m})$ & 38.8 & $11,12,16,19$ & $\mathrm{CH} 2$ & $3.28,3.11(\mathrm{~m})$ & 38.5 & 18,19 \\
\hline $17^{\prime}$ & $\mathrm{CH} 2$ & $3.16,3.04(\mathrm{~m})$ & 37.8 & $11^{\prime}, 12^{\prime}, 16^{\prime}, 18^{\prime}$ & $\mathrm{CH} 2$ & $3.28,3.11(\mathrm{~m})$ & 38.6 & $18^{\prime}, 19^{\prime}$ \\
\hline $17 "$ & $\mathrm{CH} 2$ & $3.03,2.88(\mathrm{~m})$ & 37.6 & $11 ", 16 ", 18 ", 19 "$ & & & & \\
\hline 18 & $\mathrm{CH}$ & $5.27(\mathrm{dd}, 8.3,4.4 \mathrm{~Hz}, 1 \mathrm{H})$ & 74.7 & $9,11,17,19$ & $\mathrm{CH}$ & $5.17(\mathrm{dd}, 7.6,4.9 \mathrm{~Hz})$ & 74.7 & $9,11,19$ \\
\hline $18^{\prime}$ & $\mathrm{CH}$ & $5.35(\mathrm{dd}, 9.3,4.0 \mathrm{~Hz}, 1 \mathrm{H})$ & 75.3 & $9^{\prime}, 11^{\prime}, 17^{\prime}, 19^{\prime}$ & $\mathrm{CH}$ & $5.53(\mathrm{dd}, 8.3,4.7 \mathrm{~Hz})$ & 75.2 & $\begin{array}{l}9^{\prime}, \quad 11^{\prime}, \\
19^{\prime}\end{array}$ \\
\hline $18 "$ & $\mathrm{CH}$ & $5.22(\mathrm{dd}, 8.9,4.5 \mathrm{~Hz})$ & 75.3 & $9 ", 11 ", 17 "$ & & & & \\
\hline 19 & $\mathrm{C}$ & - & 173.6 & - & $\mathrm{C}$ & - & 173.8 & - \\
\hline $19^{\prime}$ & $\mathrm{C}$ & - & 173.7 & - & $\mathrm{C}$ & - & 173.8 & - \\
\hline $19 "$ & $\mathrm{C}$ & - & 173.8 & - & & & & \\
\hline
\end{tabular}

Table 5. Antioxidant activity of Prunella vulgaris defatted seed methanolic extract, pure isolated compounds and gallic acid $\left(\mathrm{IC}_{50}\right)-$ Activité antioxydante de l'extrait méthanolique de graines dégraissées de Prunella vulgaris, des composés purs isolés et de l'acide gallique $\left(I_{50}\right)$.

\begin{tabular}{lllllll}
\hline $\mathbf{I C}_{\mathbf{5 0}}\left(\mu \mathrm{g} \cdot \mathrm{ml}^{-1}\right)$ & $\begin{array}{l}\text { Prunella vulgaris } \\
\text { DSME }\end{array}$ & $\begin{array}{l}\text { Rosmarinic } \\
\text { acid }\end{array}$ & Salviaflaside & $\begin{array}{l}\text { Amolsamic } \\
\text { acid A }\end{array}$ & $\begin{array}{l}\text { Amolsamic } \\
\text { acid B }\end{array}$ & Gallic acid \\
\hline DPPH assay & $21.12 \pm 1.63$ & $2.35 \pm 1.120 .05$ & $8.04 \pm 0.20$ & $3.07 \pm 0.13$ & $5.88 \pm 0.11$ & $0.92 \pm 0.03$ \\
ABTS assay & $13.65 \pm 0.32$ & $1.75 \pm 0.03$ & $2.99 \pm 0.14$ & $1.82 \pm 0.16$ & $3.51 \pm 0.09$ & $0.49 \pm 0.03$ \\
\hline
\end{tabular}

rosmarinic acid moieties. NMR data of compound 2 were relatively similar to compound 1 , but ${ }^{13} \mathrm{C}-\mathrm{NMR}$ data showed the presence of 54 carbons, $3 \mathrm{CH}_{2}, 21 \mathrm{CH}$ and $30 \mathrm{C}$. Comparing compounds 1 and 2 , most of the ${ }^{1} \mathrm{H}$ and ${ }^{13} \mathrm{C}$ signals of 1 were also present in the spectra of 2, at the exception of the signal for H-15, this lacking signal indicating the junction of the third rosmarinic moiety at this position. The junction C-8'$\mathrm{C}-15^{\prime}$ and the presence of a furane ring at C-14' $-\mathrm{C}-15^{\prime}$ was confirmed by HMBC correlations between $\mathrm{H}-16$ ' and C-8".

These amolsamic acids are neolignan-type compounds, found for the first time in the nature. Amolsamic acid $\mathrm{A}$ is then a structural isomer of schizotenuin A, a benzofuran lignan, which was isolated from Schizonepeta tenuifolia, a species close to P.vulgaris, also belonging to Lamiaceae family (Matsuta et al., 1996). Amolsamic acid B is a trimeric derivative of rosmarinic acid. It is only the second time that a trimeric derivative of rosmarinic acid is evidenced, after two trimers isolated from Celastrus hindsii, that does not present double bonds at C-7 C-8 position on the benzofuran rings (Ly et al., 2006).

Phenolic compounds with multiple phenolic groups and catechol moieties are well-known to possess a high anti-oxidant activity (Bhatt et al., 2013). Rosmarinic acid contain four phenolic hydrogens and two catechol moieties; amolsamic acid A (1) contain seven phenolic hydrogens and three catechol moieties; and amolsamic acid B (2) contain 10 phenolic hydrogens and four 


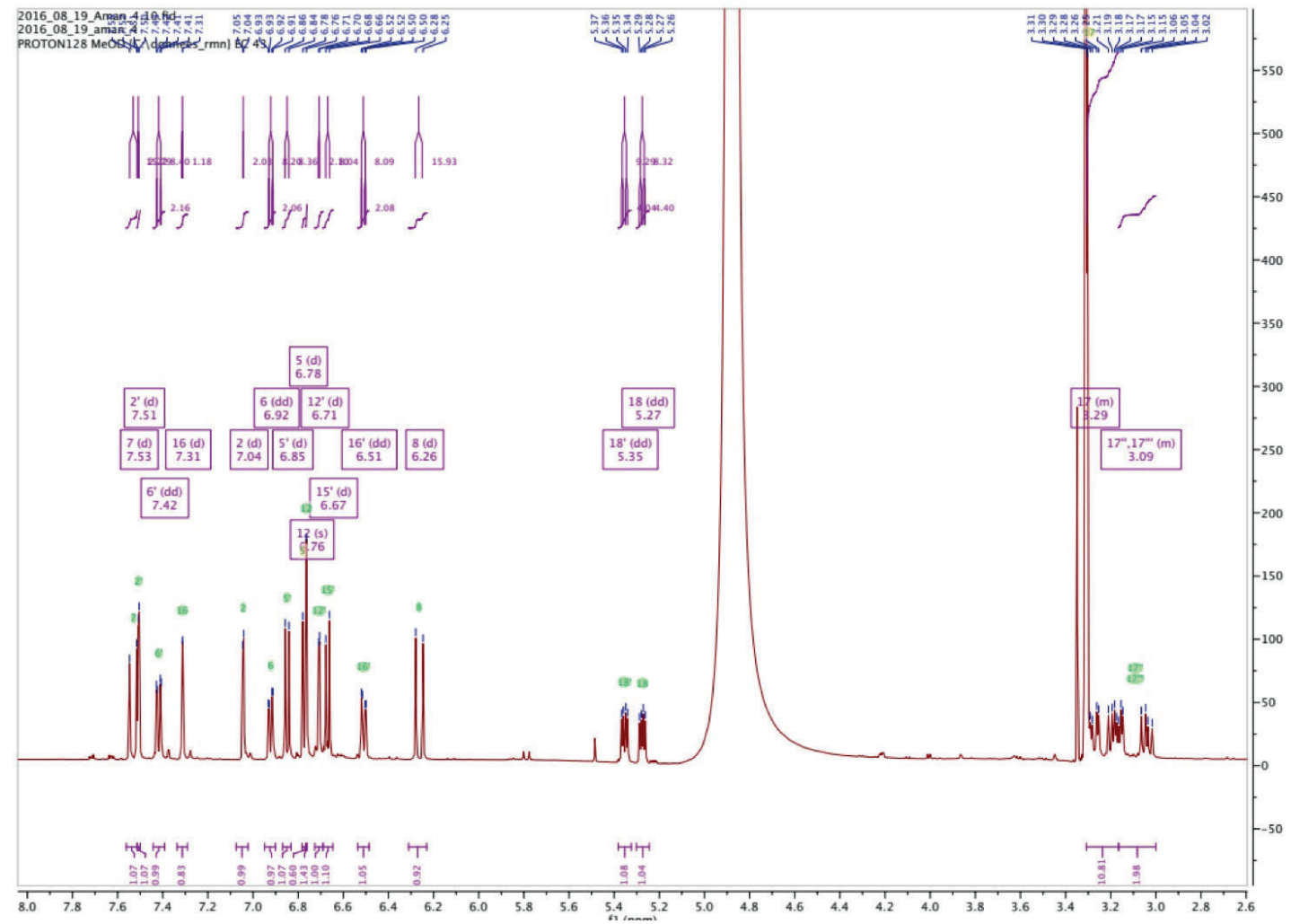

Figure 3a. Proton NMR spectrum of Amolsamic acid A (1) (500 MHz) - Spectre de RMN des protons de l'acide amolsamique A (1) (500 MHz).

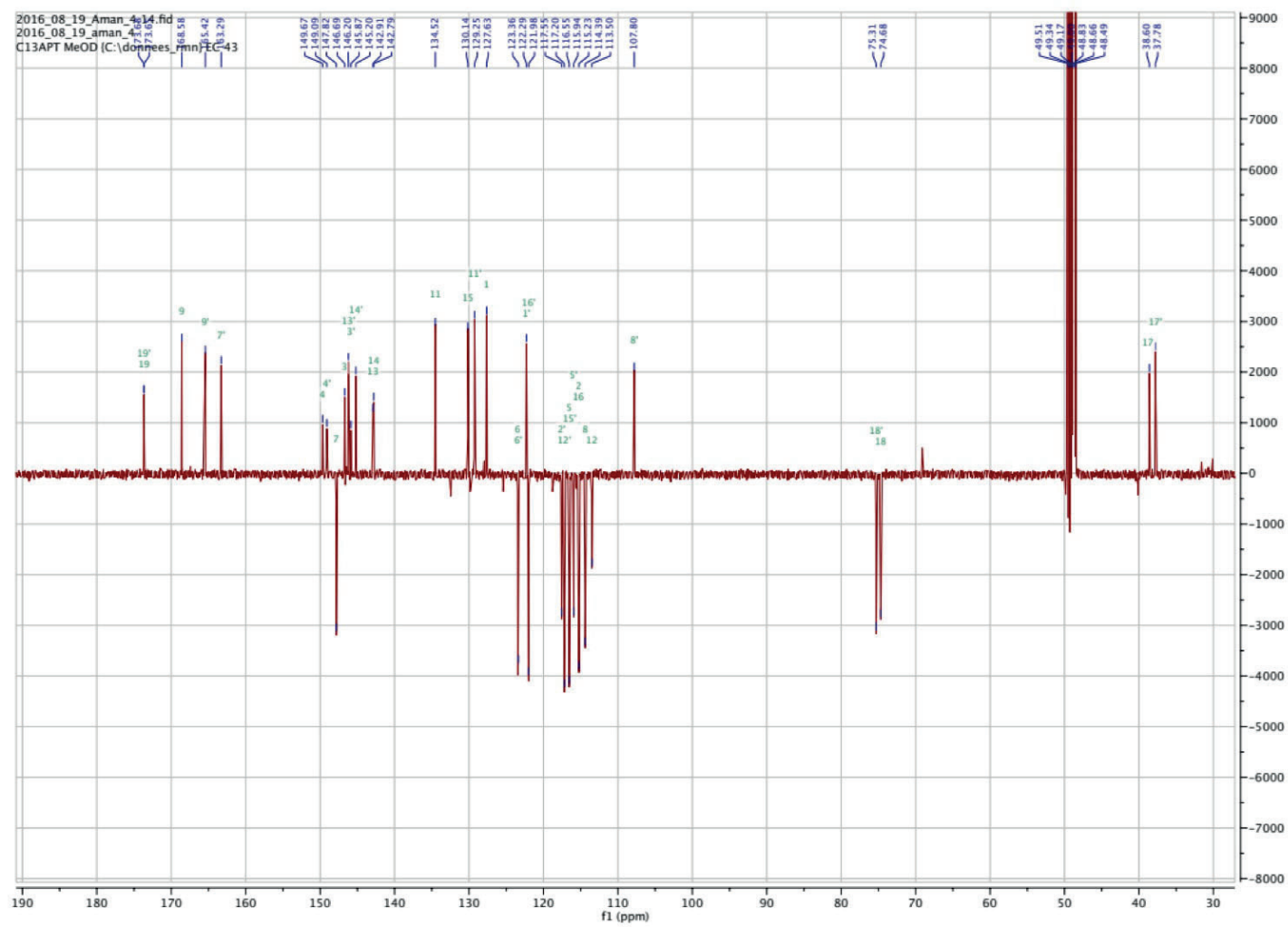

Figure 3b. Carbon NMR spectrum of Amolsamic acid A (1) (125 MHz) - Spectre de RMN du carbone de l'acide amolsamique A (1) (125 MHz). 


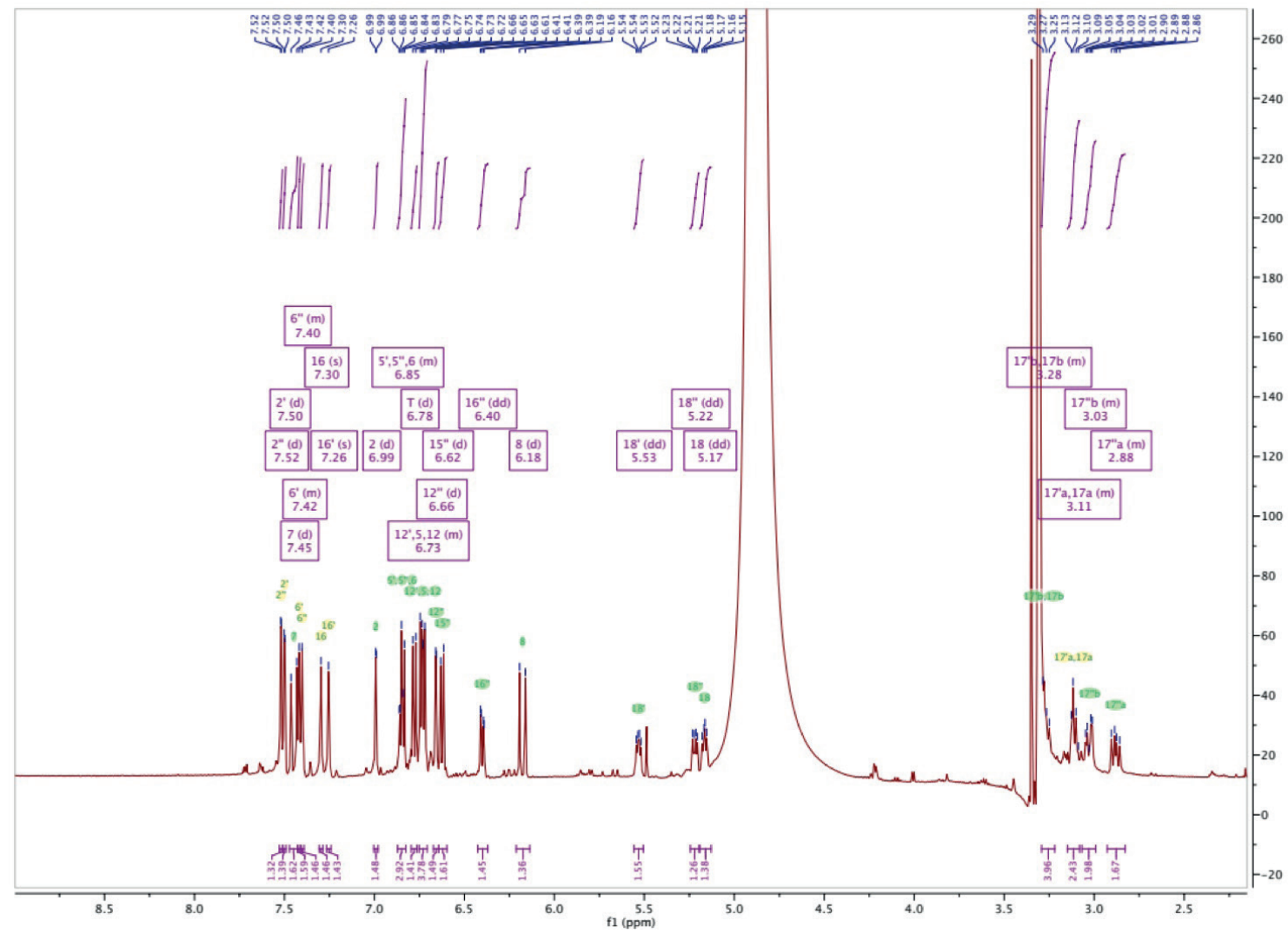

Figure 3c. ${ }^{1} \mathrm{H}-\mathrm{NMR}$ spectrum of Amolsamic acid B (2) - Spectre ${ }^{1} H$-RMN de l'acide amolsamique B (2).

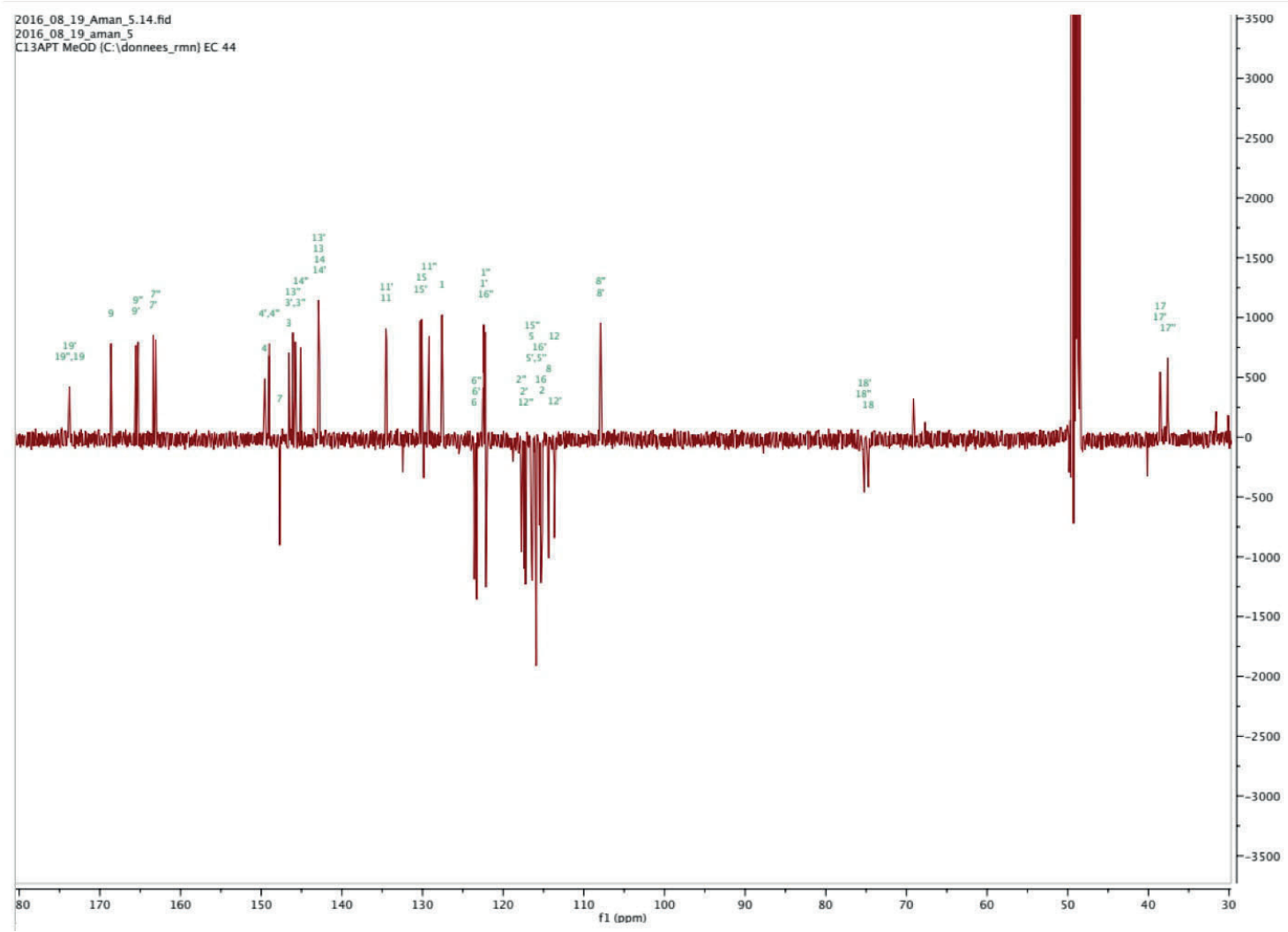

Figure 3d. ${ }^{13} \mathrm{C}$ NMR spectrum of Amolsamic acid B (2) - Spectre $R M N{ }^{13} \mathrm{C}$ de l'acide amolsamique B (2). 
a

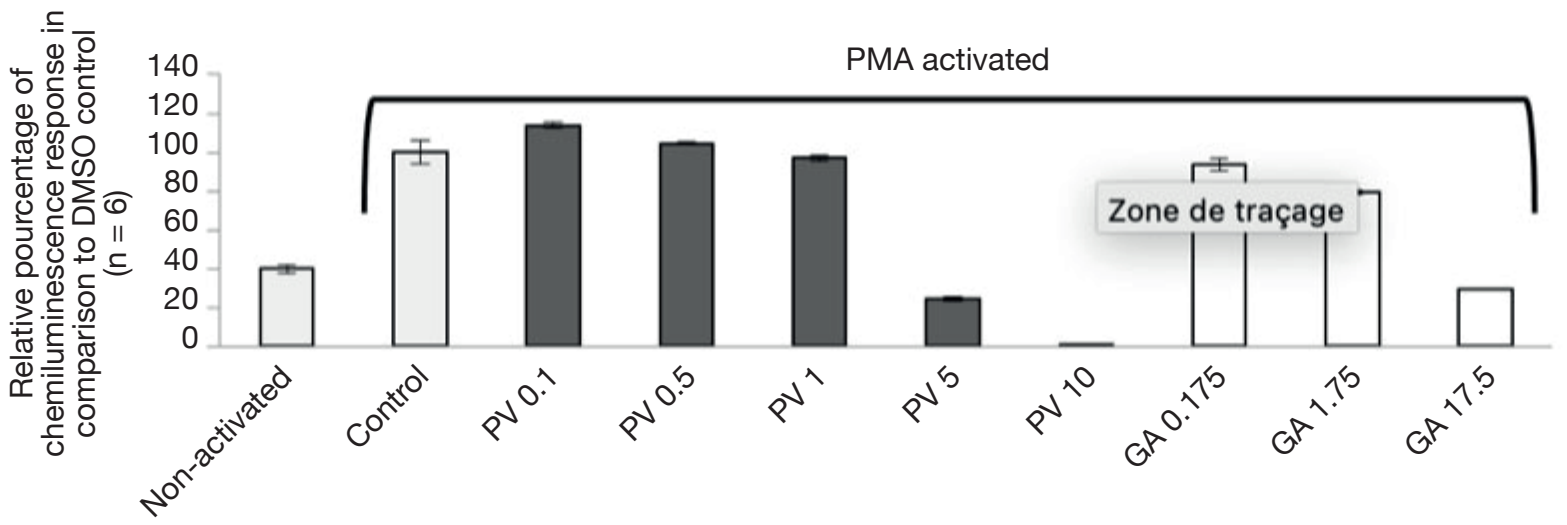

Final concentration $\left(\mu \mathrm{g} \cdot \mathrm{ml}^{-1}\right)$

b

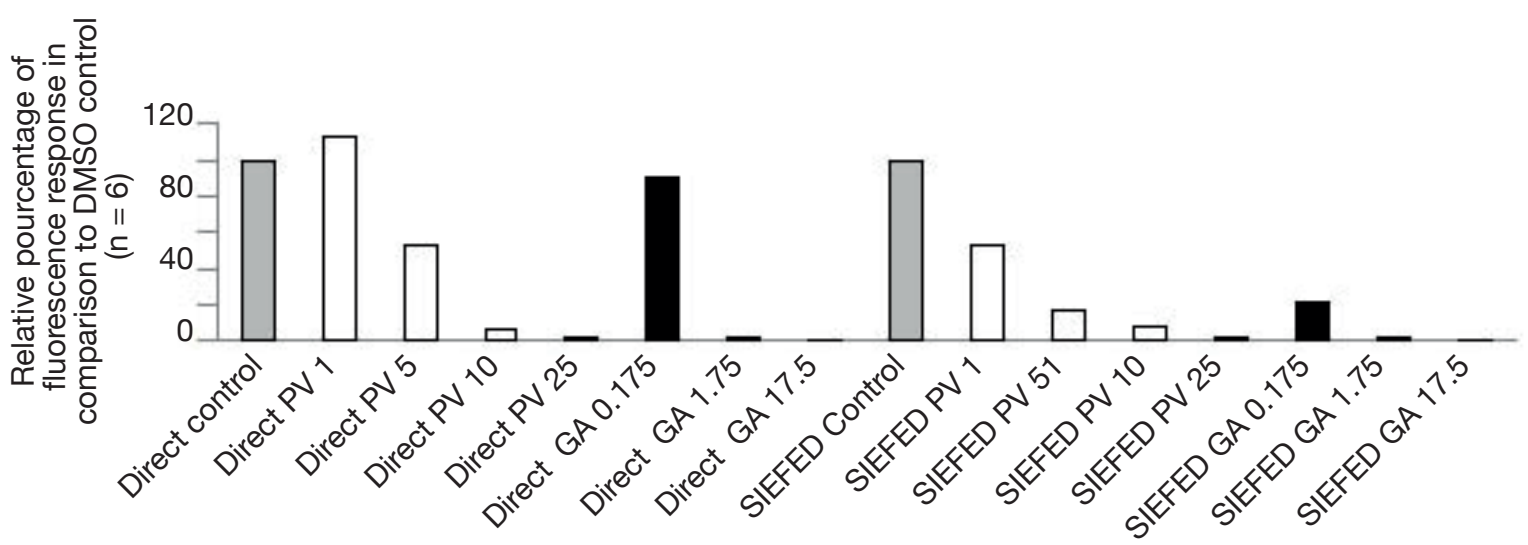

Final concentration $\left(\mu \mathrm{g} \cdot \mathrm{ml}^{-1}\right)$

c

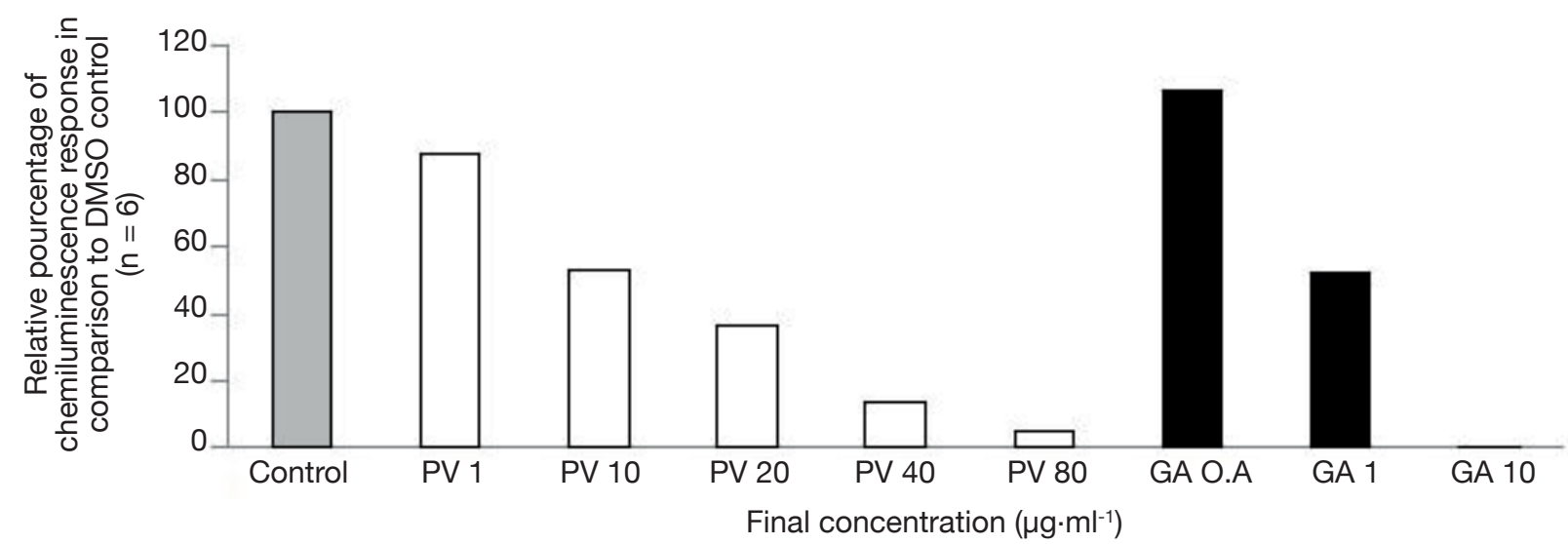

Figure 4. Anti-inflammatory activity of Prunella vulgaris seed extract and gallic acid - Activité anti-inflammatoire de l'extrait de graines de Prunella vulgaris et de l'acide gallique.

a. effect of $P$. vulgaris seed extract and reference gallic acid in modulating ROS production - effet de l'extrait de graines de P. vulgaris et de l'acide gallique de référence dans la modulation de la production de ROS; b. effect of $P$. vulgaris seed extract and reference molecule (gallic acid) in modulating MPO activity using direct and SIEFED assay - effet de l'extrait de graines de P. vulgaris et de la molécule de référence (acide gallique) dans la modulation de l'activité MPO à l'aide de l'essai direct et de l'essai SIEFED; c. effect of P. vulgaris seed extract and reference molecule (gallic acid) in modulating Horseradish peroxide activity - effet d'un extrait de graines de P. vulgaris et d'une molécule de référence (acide gallique) sur la modulation de l'activité du peroxyde de raifort. 
catechol moieties. With the presence of all these compounds, $P$. vulgaris DSME can potentially exhibit high antioxidant activity. In order to confirm this hypothesis, we investigated the antioxidant activity of $P$. vulgaris DSME using a wide range of techniques.

Phenolic compounds in food scavenge free radicals using three methods: hydrogen atom transfer, electronproton transfer and/or sequential proton loss-electron transfer (Chen et al., 2015). DPPH radical scavenging activity denotes the ability of the sample to donate hydrogen atoms and stabilize DPPH free radical, while ABTS radical scavenging activity represents the ability of sample to donate electrons.

A dose dependent increase in DPPH and ABTS antioxidant activities with increasing concentration was observed for the P. vulgaris DSME and gallic acid. Prunella vulgaris DSME exhibited high DPPH $\left(\mathrm{IC}_{50}\right.$ : $\left.21.1 \mu \mathrm{g} \cdot \mathrm{ml}^{-1}\right)$ and ABTS $\left(\mathrm{IC}_{50}: 13.7 \mu \mathrm{g} \cdot \mathrm{ml}^{-1}\right)$ radical scavenging activities. Previous experimentations in the literature on the methanolic extract of flowering stalks from P. vulgaris revealed a DPPH inhibition activity of $35.4 \%$ and a ABTS inhibition activity of $61.7 \%$ at the concentration of $100 \mu \mathrm{g} \cdot \mathrm{ml}^{-1}$ (Seo et al., 2010). Outcomes of the present study show that P. vulgaris DSME is much more active than the extract obtained from flowering stalks. Rosmarinic acid and rutin form the major components of $P$. vulgaris aerial parts (Golembiovska, 2014). Rutin exhibits a relatively weak radical scavenging activity (Sroka, 2005). On the other hand, P. vulgaris seeds contain amolsamic acid A, amolsamic acid B, salviaflaside and rosmarinic acid as the major phenolic components. As pure compounds, compared to the crude extract, rosmarinic acid and amolsamic acid A presented the strongest antioxidant activity (Table 5). The presence of the benzofuran neolignans (amolsamic acids A and B) with multiple phenolic hydrogens and catechol moieties could be one of the reasons for this high free radical scavenging activity. In order to establish a better understanding of the PV- DSME antioxidant behavior and exploring the possibilities of using it as functional food, we evaluated its cellular antioxidant and anti-inflammatory activities.

Neutrophils are white blood cells, which are primarily involved in the defense mechanism of the human body. They kill pathogenic microorganisms by phagocytosis and production of reactive oxygen species (ROS). In the present study we used PMA to activate NADPH oxidase (by activation of protein kinase $\mathrm{C}$ ) in neutrophils which results in ROS production. This ROS production is coupled with lucigenin chemiluminescence (lucigenin cation radical reacts with superoxide anion to emit light). A dose dependent increase in cellular antioxidant activities with increasing concentration was observed for the P. vulgaris DSME and gallic acid (see figure 4a). At very low concentrations (below $1 \mu \mathrm{g} \cdot \mathrm{ml}^{-1}$ ) DSME shows a pro-oxidant effect. However, by increasing the concentration (above $1 \mu \mathrm{g} \cdot \mathrm{ml}^{-1}$ ) a very strong superoxide anion quenching activity can be observed. Surprisingly, $P$. vulgaris DSME exhibits a lower $\mathrm{IC}_{50}$ $\left(3.7 \mu \mathrm{g} \cdot \mathrm{ml}^{-1}\right)$ even when compared with gallic acid $\left(6.9 \mu \mathrm{g} \cdot \mathrm{ml}^{-1}\right)$ which is considered to be a very strong antioxidant. The strong activity of $P$. vulgaris DSME possibly arises from to the presence of amolsamic acid A and B. These phenolic acids contain multiple phenolic hydrogens, which react with the superoxide anion radical resulting in its deactivation. It could be possible that cytotoxicity of seed extracts towards neutrophils is responsible for this cellular activity. To infirm this, we performed a cytotoxicity assay, and found cell viability $>98 \%$ for DMSO control, DSME $5 \mu \mathrm{g} \cdot \mathrm{ml}^{-1}$ and DSME $10 \mu \mathrm{g} \cdot \mathrm{ml}^{-1}$ in the test conditions. This confirms that the DSME is not toxic towards neutrophils. This indicates that consumption of P. vulgaris DSME (or whole seeds) could reduce the oxidative damage resulting from the neutrophil activity.

The anti-inflammatory behavior of the P. vulgaris seed extract was also characterized by its ability to modulate the activity of MPO enzyme. MPO is a peroxidase enzyme, which is secreted by neutrophils as a part of the host defense mechanism. The ability of seed extract to modulate the activity of MPO was investigated using two assays: a direct assay and SIEFED assay (Figure 4b). Similar concentrations were used in both the assays to estimate the comparative activity. In both direct and SIEFED assays, a dose dependent increase in MPO inhibition activity was observed. In direct assay, at $1 \mu \mathrm{g} \cdot \mathrm{ml}^{-1}$ (lowest concentration used), P. vulgaris DSME showed a prooxidant effect, however with increasing concentration, a strong MPO deactivation activity was observed. Higher activity of $P$. vulgaris DSME was observed in SIEFED assay $\left(\mathrm{IC}_{50} 1.1 \mu \mathrm{g} \cdot \mathrm{ml}^{-1}\right)$ when compared with direct assay $\left(\mathrm{IC}_{50} 5.1 \mu \mathrm{g} \cdot \mathrm{ml}^{-1}\right)$. During the SIEFED assay, MPO enzyme (active or deactivated by phenolic compounds) is captured by the polyclonal antibodies and the rest solution is washed away. In this way the side reaction of free polyphenols and other compounds with the MPO substrate can be excluded and a true activity is obtained (Franck et al., 2005). The possible role of amolsamic acids A and B as electron donor for reduction of MPO or scavenging of ROS produced by MPO could explain the high activity of $P$. vulgaris DSME. This data show that components of $P$. vulgaris DSME can effectively bind with MPO or scavenge the harmful products resulting from their activity.

To complement the results obtained using neutrophil and MPO models, we also tested the ability of DSME to modify the oxidative response of the $\mathrm{HRP} / \mathrm{H}_{2} \mathrm{O}_{2}$ system. As for neutrophil and MPO models, a similar dose-dependent inhibitory activity of L012 oxidation catalyzed by $\mathrm{HRP} / \mathrm{H}_{2} \mathrm{O}_{2}$ was observed in the presence 
of increasing concentrations of DSME (Figure 4c). The strong HRP enzyme modulation activity of the seed extract could be attributed to the presence of a strong hydrogen donor such as amolsamic acids A or B. The antioxidant and anti-inflammatory activity results obtained using all the three models (neutrophils, MPO and HRP), indicate that consumption of P. vulgaris DSME (or whole seeds) can potentially prevent/reduce the inflammatory damage of body tissues resulting from some oxidative reactions.

\section{CONCLUSIONS}

In an attempt to assess the nutritional potential of P. vulgaris seeds, their protein, lipid and minerals contents were determined. An omega-3 rich oil was detected, an interesting amino acids profile, as well as the presence of two new polyphenolic compounds - amolsamic A\&B - described herein for the first time. The polar extract of the seed as well as the two new compounds exhibited strong antioxidant and peroxidase inhibition activities, both on different biochemical and cellular models. Concerning the nutritional aspects, with $17 \%$ proteins (on dry weight) and an interesting amino acid profile, P.vulgaris seeds could be used in food formulations. Moreover, $P$. vulgaris seeds are an excellent source of fat, particularly rich in polyunsaturated fatty acids such as $\alpha$-linolenic (55\%) and linoleic (16\%) acids. Due to this interesting FA profile, $P$. vulgaris seeds could be used for omega-3 fatty acid supplementation in diet. Furthermore, the seeds showed an interesting antioxidant potential with a better activity in some models than the reference compound gallic acid, and a strong anti-inflammatory activity on neutrophils, MPO and HRP models. All these findings highlight the real health promoting potential of $P$. vulgaris seeds, if used as food or food supplement.

\section{List of abbreviations}

ABTS : 2,2-azinobis (3-ethylbenzothiazoline)-6 sulphonic acid

CL : chemiluminescence

DAG : diacylglycerol

DMSO : imethyl Sulfoxide

DSME : Defatted Seed Methanolic Extract

DPPH : 2,2-diphenyl-1-picryhydrazyl

EAA : Essential Amino Acids

ESI : Electrospray Ionisation

FA : Fatty Acid

FBFS : Field Border Flowering Strips

FFA : Free Fatty Acid

GA : Gallic Acid

GC : Gas Chromatography
HPLC : High Performance Liquid Chromatography

HR-MS : High-Resolution Mass Spectrometry

HRP : Horseradish Peroxidase

IC50 : Half Maximal Inhibitory Concentration

MAG : Monoacylglycerol

MPO : Myeloperoxidase

MS : Mass Spectrometry

MUFA : Monounsaturated Fatty Acids

NADPH : Nicotinamide Adenine Dinucleotide Phosphate

NEA : Non-Essential Amino Acids

NMR : Nuclear Magnetic Resonance Spectroscopy

PBS : Phosphate-Buffered Saline

PMA : Phorbol Myristate Acetate

PMN : Polymorphonuclear cells

PUFA : Polyunsaturated Fatty Acids

PV : Prunella vulgaris seed extract

ROS : Reactive Oxygen Species

SIEFED : Specific Immuno-Extraction Followed by Enzyme

Detection

SPE : Solid Phase Extraction

TAG : Triacylglycerol

\section{Bibliography}

AOAC International, 2007. Method 992 23. Official methods of analysis of AOAC International. $18^{\text {th }}$ ed. Rockville, MD, USA : AOAC International.

Benbarek H. et al., 1999. High concentrations of histamine stimulate equine polymorphonuclear neutrophils to produce reactive oxygen species. Inflamm. Res., 48, 594601, doi.org/10.1007/s000110050509.

Bhatt R., Mishra N. \& Bansal P.K., 2013. Phytochemical, pharmacological and pharmacokinetics effects of rosmarinic acid. J. Pharm. Sci. Innov., 2, 28-34, doi. org/10.7897/2277-4572.02215

Chen Y., Xiao H., Zheng J. \& Liang G., 2015. Structurethermodynamics-antioxidant activity relationships of selected natural phenolic acids and derivatives: an experimental and theoretical evaluation. PLoS One, 10(3), e0121276, doi.org/10.1371/journal.pone.0121276

Chevallier A., 2016. Encyclopedia of herbal medicine. $2^{\text {nd }}$ ed. New York, NY, USA: Barnes \& Nobles.

EDQM, 2020. European Pharmacopoeia. $10^{\text {th }}$ ed. Strasbourg, France : Council of Europe.

EFSA, 2011. Consolidated list of article 13 health claims. List of references received by EFSA. Part 4. Parma, Italy: EFSA, www.efsa.europa.eu/sites/default/files/topic/ ndaart13ref04.pdf, (10 November 2021).

Floegel A. et al., 2011. Comparison of ABTS/DPPH assays to measure antioxidant capacity in popular antioxidant-rich US foods. J. Food Compos. Anal., 24, 1043-1048, doi. org/10.1016/j.jfca.2011.01.008

Franck T. et al., 2005. Development of an enzyme-linked immunosorbent assay for specific equine neutrophil myeloperoxidase measurement in blood.J. Vet.Diagnostic Investig., 17, 412-419. 
Franck T. et al., 2013. Differentiation between stoichiometric and anticatalytic antioxidant properties of benzoic acid analogues: a structure/redox potential relationship study. Chem. Biol. Interact., 206, 194-203, doi.org/10.1016/j. cbi.2013.09.009

Goering H.K. \& Van Soest P.J., 1970. Forage fiber analysis. USDA Agric. Handbook No. 379. Washington: USDAARS.

Golembiovska O., 2014. Simultaneous determination of flavonoids and phenolic acids in different parts of Prunella vulgaris L. by high-performance liquid chromatography with photodiode array detection. Int. J. Pharmacognosy Phytochem. Res., 29, 1248-1255.

Gu X., Li Y., Mu J. \& Zhang Y., 2013. Chemical constituents of Prunella vulgaris. J. Environ. Sci., 25, S161-3, doi. org/10.1016/S1001-0742(14)60648-3

Gunstone F.D., ed., 2011. Vegetable oils in food technology: composition, properties and uses. Chichester, UK: John Wiley \& Sons.

Gunstone F.D., Harwood J.L. \& Padley F.B., 1994. The lipid handbook. $2^{\text {nd }}$ ed. London: Chapman and Hall.

Huang N. et al., 2009. Rosmarinic acid in Prunella vulgaris ethanol extract inhibits lipopolysaccharide-induced prostaglandin E2 and nitric oxide in RAW 264.7 mouse macrophages. J. Agric. Food Chem., 57, 10579-10589, doi.org/10.1021/jf9023728

Kalle R.\& Sõukand R., 2012.Historical ethnobotanical review of wild edible plants of Estonia (1770s-1960s). Acta Soc. Bot. Pol., 81, 271-281, doi.org/10.5586/asbp.2012.033

Loukou A.L. et al., 2011. Effect of harvest time on seed oil and protein contents and compositions in the oleaginous gourd Lagenaria siceraria (Molina) Standl. J. Sci. Food Agric., 91, 2073-2080, doi.org/10.1002/jsfa.4422.

Ly T.N., Shimoyamada M. \& Yamauchi R., 2006. Isolation and characterization of rosmarinic acid oligomers in Celastrus hindsii Benth leaves and their antioxidative activity. J. Agric. Food Chem., 54, 3786-3793, doi. org/10.1021/jf052743f

Matsuta M., Kanita R., Saito Y. \& Yamashita A., 1996. The 3-alpha-hydroxysteroid dehydrogenase inhibitory active flavonoids and phenylpropanoids from Schizonepeta spikes. Nat. Med., 50, 204-211.

Melo D., MacHado T.B. \& Oliveira M.B.P.P., 2019. Chia seeds: an ancient grain trending in modern human diets. Food Funct., 10, 3068-3089, doi.org/10.1039/ c9fo00239a

Montserrat-De La Paz S., Marín-Aguilar F., GarcíaGiménez M.D. \& Fernández-Arche M.A., 2014. Hemp (Cannabis sativa L.) seed oil: analytical and phytochemical characterization of the unsaponifiable fraction. J. Agric. Food Chem., 62, 1105-1110, doi. org/10.1021/jf404278q
Paul A. et al., 2015. Proximate analysis of seeds from some field border flowering strips. Sci.Bull. Ser. F Biotechnol., 19, 354-359.

Paul A. et al., 2016. Nutritional composition and rearing potential of the meadow grasshopper (Chorthippus parallelus Zetterstedt). J. Asia Pac. Entomol., 19, 11111116, doi.org/10.1016/j.aspen.2016.09.012

Qu Z. et al., 2017. Prunella vulgaris L., an edible and medicinal plant, attenuates scopolamine-induced memory impairment in rats. J. Agric. Food. Chem., 65 , 291-300, doi.org/10.1021/acs.jafc.6b04597

Rasool R. \& Ganai B.A., 2013. Prunella vulgaris L. : a literature review on its therapeutic potentials. Pharmacologia, 4, 441-448, doi.org/10.5567/ pharmacologia.2013.441.448

Sárosi S. et al., 2011. Effect of different plant origins and climatic conditions on the total phenolic content and total antioxidant capacity of self-heal (Prunella vulgaris L.). Acta Hortic., 925, 49-55, doi.org/10.17660/ ActaHortic.2011.925.5

Seo J.K. et al., 2010. Antibacterial and antioxidant activities of solvent extracts from different parts of hagocho (Prunella vulgaris). J. Korean Soc. Food. Sci. Nutr., 39, 1425-1432, doi.org/10.3746/jkfn.2010.39.10.1425

SPF Santé Publique, 2016. Avis 9285 - Recommandations nutritionnelles pour la Belgique - 2016, www. health.belgium.be/fr/avis-9285-recommandationsnutritionnelles-pour-la-belgique-2016, (April 14, 2020).

Sroka Z., 2005. Antioxidative and antiradical properties of plant phenolics. Z. Naturforschung C, 60, 833-843, doi. org/10.1515/znc-2005-11-1204

Tezuka Y. et al., 1998. Constituents of roots of Salvia deserta Schang. (Xinjiang-Danshen). Chem. Pharm. Bull., 46, 107-112.

Uyttenbroeck R. et al., 2016. Pros and cons of flowers strips for farmers. A review. Biotechnol. Agron. Soc. Environ., 20, 225-235.

Vaghela M.N. \& Kilara A., 1995. A rapid method for extraction of total lipids from whey protein concentrates and separation of lipid classes with solid phase extraction. J. Am. Oil Chem. Soc., 72, 1117-1121, doi.org/10.1007/ BF02540976

Wang S.J. et al., 2019. Prunella vulgaris: a comprehensive review of chemical constituents. Pharmacological effects and clinical applications. Curr. Pharm. Des., 25, 359369, doi.org/10.2174/1381612825666190313121608

WHO, 2007. Protein and amino acid requirements in human nutrition. Geneva, Switzerland: WHO, http://whqlibdoc. who.int/trs/WHO_TRS_935_eng.pdf?ua=1, (February 20, 2014).

(35 ref.) 